\title{
Nam Theun 2 Reservoir four years after commissioning: significance of drawdown methane emissions and other pathways
}

\section{Le réservoir de Nam Theun 2 quatre ans après la mise en service : émissions de méthane par la zone de marnage et autres voies d'émission}

D. Serça(1) ${ }^{(1)}$ C. Deshmukh ${ }^{(1)}$, S. Pighini( ${ }^{(2)}$, P. Oudone ${ }^{(2)}$, A Vongkhamsao (2), P. Guédant ${ }^{(2)}$, W. Rode ${ }^{(2)}$, A. Godon ${ }^{(2)}$, V. Chanudet ${ }^{(3)}$, S. Descloux ${ }^{(3)}$ and F. Guérin ${ }^{(1,4)}$

(1) Laboratoire d'Aérologie, Université de Toulouse, CNRS, UPS, 14 Avenue E. Belin, 31400 Toulouse, France serd@aero.obs-mip.fr

(2) Nam Theun 2 Power Company Limited (NTPC), Environment \& Social Division - Water Quality and Biodiversity Dept.- Gnommalath Office, PO Box 5862, Vientiane, Lao PDR

(3) Électricité de France, Hydro Engineering Centre, Sustainable Development Dpt, Savoie Technolac, 73373 Le Bourget du Lac, France

(4) IRD; UR 234, GET; 14 Avenue E. Belin, 31400, Toulouse, France

\begin{abstract}
Hydro-reservoirs are recognized as potentially significant emitters of methane at the global scale. However, there are still large uncertainties in estimating such emissions at this scale due to the lack of comprehensive measurements of methane emissions in a wide range of climatic zones, for hydro-reservoirs with variable characteristics, and including all emissions pathways. This study presents an assessment of methane emissions for the 2013 year, that is four years after commissioning, for the Nam Theun 2 hydro-system, a $489 \mathrm{~km}^{2}$ subtropical reservoir with a large drawdown area. All of the major pathways have been computed here, i.e., ebullition, diffusion, degassing, emissions from the drawdown area, and diffusion from downstream, and included in an emission budget. Emissions from the upstream area strongly dominate when compared to the downstream ones, a feature quite specific to the Nam Theun 2 reservoir. The drawdown area and the emissions by diffusion downstream represented a small contribution to the total emissions. About half of the methane is emitted during the four months of the warm dry season (from mid-February to Mid-June). Total methane emissions in NT2 have decreased from $35.6 \pm 2.6 \mathrm{Gg}_{\left(\mathrm{CH}_{4}\right)}$ year ${ }^{-1}$ in 2010 to $24.5 \pm 1.5 \mathrm{Gg}\left(\mathrm{CH}_{4}\right)$ year $^{-1}$ in 2013 though this difference was not found to be quite statistically significant.
\end{abstract}

Key words - methane, emission pathways, assessment, drawdown area, hydropower, Nam Theun 2 reservoir 
Résumé - Les réservoirs hydroélectriques sont reconnus comme pouvant être des sources significatives de méthane à l'échelle mondiale. Il existe cependant de fortes incertitudes sur ces émissions. Cela est dû notamment au manque de mesures des émissions de méthane sur l'ensemble des zones climatiques, pour des réservoirs hydroélectriques de caractéristiques variables, et pour l'ensemble des voies d'émission. Cette étude présente une évaluation des émissions de méthane pour l'année 2013, soit quatre ans après la mise en service du barrage de Nam Theun 2, un réservoir subtropical de $489 \mathrm{~km}^{2}$ caractérisé par une grande zone de marnage. Les principales voies d'émission ont été ici prises en compte, à savoir l'ébullition, la diffusion, le dégazage, les émissions par la zone de marnage, et la diffusion à l'aval, pour évaluer le bilan des émissions à l'échelle du réservoir. Les émissions de la zone amont dominent fortement par comparaison avec celles de la zone aval, une caractéristique assez spécifique au réservoir de Nam Theun 2. Les émissions par la zone de marnage et la diffusion à l'aval représentent au final une contribution mineure aux émissions totales. Environ la moitié du méthane est émis pendant les quatre mois de la saison sèche et chaude (de mi-février à mi-juin). Les émissions totales de méthane à NT2 sont passées de $35,6 \pm 2,6 \mathrm{Gg}\left(\mathrm{CH}_{4}\right) \mathrm{an}^{-1}$ en 2010 à $24,5 \pm 1,5 \mathrm{Gg}\left(\mathrm{CH}_{4}\right) \mathrm{an}^{-1}$ en 2013 bien que cette différence ne soit pas statistiquement significative.

Mots-clés - méthane, voies d'émission, estimation, zone de marnage, hydroélectricité, réservoir de Nam Theun 2

\section{INTRODUCTION}

Methane is the second major greenhouse gas after $\mathrm{CO}_{2}$, and contributes to $43 \%$ of the anthropogenic radiative forcing (IPCC, 2013). After a decade of flat evolution, methane mixing ratio has been steadily raising since 2007-2008. Methane can be found in the atmosphere at a mixing ratio of $1875 \mathrm{ppbv}$, a level never reached before (IPCC, 2013). As a matter of consequences, in the context of the climate change and global warming, any attempt to better constrain methane emissions from the surface is of high relevance. For the last twenty years, artificial reservoirs have been recognized as a potential significant source of methane to the atmosphere, but still, the two main estimates of methane emission from reservoirs at the global scale (St Louis et al., 2000; Barros et al., 2011) differ by a factor 10 . This large discrepancy is due to the lack of measurements in reservoirs encompassing a whole range of climatic regions and a variety of characteristics (size, shape, age, mean depth, flooded organic matters (OM), ...). Large uncertainties can also be linked to poor investigations of the spatial and temporal emission variability within the studied sites, though some studies have been focusing on this specific issue (Abril et al., 2005; DelSontro et al., 2011; Zhao et al., 2013; Deshmukh et al., 2014; Musenze et al., 2014; Sahlée et al., 2014; Guérin et al., 2016). As a matter of consequences, period or area of intense emissions, the so-called hot moments and spots, might have been overlooked in previous studies. It is only very recently that studies were conducted in Asian reservoirs (Chen et al., 2011; Chanudet et al., 2011; Yang etal., 2012, 2013; Xiao et al., 2013; Guérin et al., 2016; Deshmukh et al., 2016), although this region concentrates $60 \%$ 
of all large dams in the World (Tremblay et al., 2005) and a large number of ongoing projects to be built in the next decade.

In reservoirs, $\mathrm{CH}_{4}$ is produced in anoxic sediments and flooded soils from the decomposition of OM (Galy-Lacaux et al., 1997; Guérin et al., 2008). Once produced, methane can be released to the atmosphere via four main pathways: diffusion and ebullition at the reservoir surface, degassing and diffusive emissions downstream of the dam. Each of these pathways is regulated by a variety of physical, chemical and biological parameters controlling the actual amount of $\mathrm{CH}_{4}$ eventually emitted to the atmosphere. Diffusion is the most intensively monitored pathway in reservoirs (Barros et al., 2011, and references therein), and is sometime the only one accounted for. Ebullition has been recently under scrutiny with various studies specifically focused on that pathway (DelSontro et al., 2010; Deshmukh et al., 2014). It is admitted that this pathway must have been overlooked so far and could be a major, if not dominant, $\mathrm{CH}_{4}$ emission pathway in reservoirs. Degassing downstream the turbines is a wellknown phenomenon linked to pressure change and turbulence once the water has been released (Galy-Lacaux et al., 1997). Though it is not a new pathway, downstream degassing has been neglected in the past decade, even if few studies pointed out (Abril et al., 2005; Kemenes et al., 2007; Maeck et al., 2014; Teodoru et al., 2015) that it could be a significant one. Results from the Petit Saut reservoir study in French Guiana (Abril et al., 2005) have shown that degassing and emissions from the river downstream of the dam, if not the main pathway during the two first years after impoundment, becomes heavily dominant when accounted over the span of the first ten years after impoundment. Emissions from the drawdown area are newly studied in some reservoirs like the Three Gorges reservoir (Chen et al., 2009, 2011) in China, and constitute a fifth emission pathway for methane. There is not yet any clear evidence whether it can be a major pathway at the scale of a hydro-reservoir, and what would be the controlling emission factors in this case.

The objective of the present study is to present the comprehensive assessment of methane emissions at the scale of the Nam Theun 2 reservoir for the year 2013, i.e. four year after impoundment, together with a comparison of the previous years emissions. This assessment is one of the very few to compute the four emission pathways described above from direct methane concentrations and flux measurements collected during a fortnightly monitoring since impoundment. Additionally, emissions from the drawdown area were measured during two field campaigns. Temporal evolution of the total emissions and of the individual pathways upscaled for the NT2 hydro-system will be described at the seasonal and annual scale. Underlying factors acting on the different pathways will be also discussed.

\section{MATERIAL AND METHODS}

\subsection{Study site}

Nam Theun 2 reservoir is a transbasin project diverting water from the 
Nam Theun into the Xe Bangfai River. Reservoir covers an area of $489 \mathrm{~km}^{2}$ when at its maximal operating level (538 m ASL), a level first reached in October 2009. The powerhouse has been commissioned on March 2010 (Descloux et al., 2015a). Reservoir surface can go down to a theoretical minimum of $86 \mathrm{~km}^{2}$ (operating level of $525.5 \mathrm{~m} \mathrm{ASL}$ ), though the lowest water surface ever reached was $168 \mathrm{~km}^{2}$ in 2011. The surface of $489 \mathrm{~km}^{2}$ was originally covered by about $80 \%$ of different forest types (primary, degraded, light), $11 \%$ of agricultural lands, and the rest of rivers and wetlands (Descloux et al., 2011). A maximum of $325 \mathrm{~m}^{3} \mathrm{~s}^{-1}$ of water is processed through the turbines and released into the Xe Bangfai River through a $28 \mathrm{~km}$ Downstream Channel, when $2 \mathrm{~m}^{3} \mathrm{~s}^{-1}$ (instream flow) and occasional spillways are released in the Nam Theun River at the Nakai Dam (Fig. 1). Main remarkable features of the Downstream Channel include a $8 \mathrm{Mm}^{3}$ regulating pond with a regulating dam $3.5 \mathrm{~km}$ downstream the turbines, and an aeration weir built downstream of station $\mathrm{DCH} 2$, midway between the turbines and the release in the Xe Bangfai River (Fig. 1).

From mean monthly precipitation and air temperature, meteorological years can be divided into three different seasons: the Warm Wet (WW) (midJune to mid-October), the Cool Dry (CD) (mid-October to mid-February) and the Warm Dry (WD) (mid-February to midJune) seasons (NTPC, 2005). Monthly average air temperature calculated for the years 2010 to 2013 varied from $17^{\circ} \mathrm{C}$ during the $\mathrm{CD}$ season, to $27^{\circ} \mathrm{C}$ in the WD season (Descloux et al., 2015a). For the same period, mean annual rainfall was about $2600 \mathrm{~mm}$ (from 2100 to $3100 \mathrm{~mm}$ ), with $80 \%$ of the precipitation occurring during the WW season (Descloux et al., 2015a). Fluctuations in the reservoir level are directly linked with variations in precipitation since the amount of water turbined or released to the Nam Theun River is somewhat constant one month from the other. Reservoir fills up and reaches its maximum level during the WW season and its lowest level, $9 \mathrm{~m}$ below, at the end of the WD season. The large drawdown area uncovered in the WD season, up to $325 \mathrm{~km}^{2}$ in 2011 , is a noticeable feature of the NT2 reservoir. With an annual average depth of $7.8 \mathrm{~m}$ (NTPC, 2005), NT2 can be designated as a shallow reservoir.

\subsection{Sampling strategy}

We used dissolved concentrations of $\mathrm{CH}_{4}$ in water (from the surface to the bottom), together with temperature and dissolved oxygen that have been monitored at 18 different stations (Fig. 1) in the whole NT2 system fortnightly from January 2010 to December 2013. This includes 9 stations (RES1 to RES9) located in the reservoir, together with 7 stations downstream the turbines (Tailrace Channel- TRC1, Regulating Dam- REG1, artificial Downstream Channel- DCH1 to DCH4, and Nam Kathang River- NKT3) and 2 stations downstream the Nakai Dam (NTH3 and NTH4). RES9 has the specific feature to be located about $1 \mathrm{~km}$ upstream of the Water Intake feeding the turbines (Fig. 1).

The monitoring was completed by measurements conducted during two specific field campaigns in May-June 


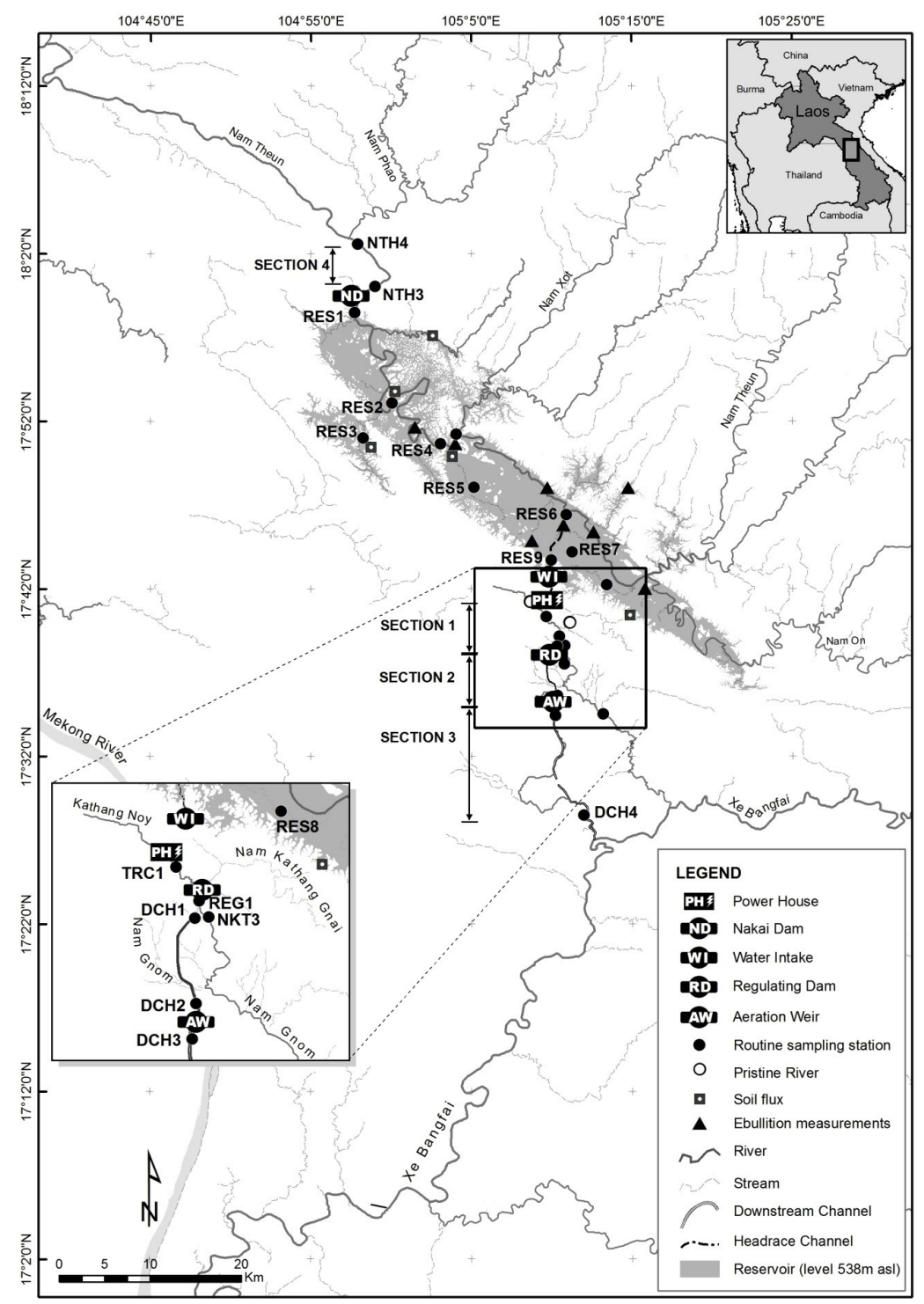

Fig. 1. Location map showing the different components of the Nam Theun 2 hydropower reservoir and the network of fortnightly sampling stations in the reservoir, upstream, Downstream Channel and downstream of the Nakai Dam. The reservoir is shown at its full capacity (538 $\mathrm{m}$ above sea level)

Fig. 1. Carte montrant les différentes composantes du réservoir hydroélectrique de Nam Theun 2 et le réseau des 18 stations de prélèvements bimestriels utilisées dans cette étude : réservoir- RES 1 à RES9, aval centrale hydroélectrique ou canal de fuite- TRC1, aval barrage bassin de démodulationREG1, canal artificiel aval- DCH1 à DCH4, aval rivière Nam Kathang- NKT3, aval barrage NakaiNTH3 et NTH4. Le réservoir est montré à sa cote maximale (538 $\mathrm{m}$ au-dessus du niveau de la mer). 
2010 and June 2011, both at the transition from the WD to the WW season, in order to investigate the emissions from the drawdown area as this phenomenon was believed to be potentially important at Nam Theun 2 (NT2) which undergoes large fluctuations in surface along the year.

\subsection{Measurements techniques}

\subsubsection{Dissolved $\mathrm{CH}_{4}$ in water}

Water samples were taken for the determination of $\mathrm{CH}_{4}$ concentration. This was done with water sampler (Abril et al., 2007) for the surface water, and with a $5 \mathrm{~L}$ sampling bottle (Uwitec ${ }^{\circledR}$ ) for the water column. Mercury chloride (1 $\mathrm{mg} \mathrm{L}^{-1}$ ) poisoned water samples were kept in serum glass vials capped with butyl stoppers and sealed with aluminium crimps (Guérin \& Abril, 2007). $\mathrm{N}_{2}$ headspace was created in the vials that were vigorously shaken before analysis to ensure an equilibration between the liquid and gas phases. $\mathrm{CH}_{4}$ concentration was determined in the sample headspace with a SRI $8610 \mathrm{C}$ gas chromatograph (Torrance, CA, USA), equipped with a flame ionization detector (FID). Calibration of the gas chromatograph was done for every ten samples using commercial gas standards (2, 10, 100 and 1010 ppmv, Air Liquid "Crystal" ${ }^{\circledR}$ " standards). Duplicate injection of samples $(0.5 \mathrm{~mL})$ showed reproducibility always better than $5 \%$. Concentrations in the water were calculated afterwards from the concentrations in the headspace using the solubility coefficient from Yamamoto et al. (1976).

\subsubsection{Ebullitive fluxes}

Ebullitive fluxes were measured with the submerged funnel technique. An Artificial Neural Network (ANN) approach linking flux measurements and physical inputs was used to conduct gap-filling and up-scaling at the reservoir and annual scale (see details about measurements and ANN approach in Deshmukh et al., 2014). ANN inputs include total static pressure (sum of hydrostatic and atmospheric pressure), variations in the total static pressure, and bottom water temperature.

\subsubsection{Diffusive fluxes from the reservoir}

Surface and atmospheric $\mathrm{CH}_{4}$ concentrations measured fortnightly at the RES1 to RES9 stations in the reservoir were used to calculate diffusive fluxes from the Thin Boundary Layer (TBL) equation (Eq. 1):

$$
\mathrm{F}=\mathrm{k}_{\mathrm{T}} \times\left(\mathrm{C}_{\mathrm{w}}-\mathrm{C}_{\mathrm{a}}\right)
$$

where: $F$ is the diffusive flux at waterair interface, $\mathrm{k}_{\mathrm{T}}$ the gas transfer velocity at a given temperature $(\mathrm{T}), \mathrm{C}_{\mathrm{w}}$ the $\mathrm{CH}_{4}$ concentration in surface water, and $\mathrm{C}_{a}$ the $\mathrm{CH}_{4}$ concentration in the surface water at equilibrium with the overlying atmosphere. Gas transfer velocities $\mathrm{k}_{\mathrm{T}}$ were computed from Equation (2):

$$
\mathrm{k}_{\mathrm{T}}=\mathrm{k}_{600} \times\left(600 / \mathrm{Sc}_{\mathrm{T}}\right)^{\mathrm{n}}
$$

with $\mathrm{k}_{600}$, the gas transfer velocity of $\mathrm{CO}_{2}$ at $20^{\circ} \mathrm{C}, \mathrm{Sc}_{\mathrm{T}}$, the Schmidt number of $\mathrm{CH}_{4}$ at a given temperature (T) (Wanninkhof, 1982), ' $n$ ' a number equal to $2 / 3$ for low wind speed $\left(<3.7 \mathrm{~m} \mathrm{~s}^{-1}\right)$ and 1/2 for higher wind speed (Jähne et al., 1987). The $k_{600}$ value was 
calculated as the average of the gas transfer velocities computed from Macintyre et al. (2010) and Guérin et al. (2007) formulations (Deshmukh et al., 2014; Guérin et al., 2016), both including the effect of wind speed. Guérin et al. (2007) also includes the effect of precipitations. The average fluxes computed from these two relationships compared well with fluxes measured at the reservoir surface (Deshmukh et al., 2014). Wind speed data at $10 \mathrm{~m}$ height were taken from the Ban Thalang meteorological station (close to RES 4, Fig. 1). $\mathrm{k}_{600}$ typically ranges between 0.9 and $51.0 \mathrm{~cm} \mathrm{hr}^{-1}$ (average $=6.7 \pm 7.1 \mathrm{~cm} \mathrm{hr}^{-1}$ ) over the course of the year for the RES1 to RES8 stations. A value of $10 \mathrm{~cm} \mathrm{hr}^{-1}$ was chosen for RES9 to take into account the strong permanent vortexes created by the Water Intake close to this station (Guérin et al., 2016).

Up-scaling of diffusive fluxes was conducted according to the statistics analysis made by Guérin et al. (2016) from which it appears that specific diffusive fluxes are to be taken into account for RES9 station. Based on the physical modelling by Chanudet et al. (2012), an area of $\sim 3 \mathrm{~km}^{2}$ all year long (i.e. whatever the water level in the reservoir) was attributed to the specific diffusive fluxes found in RES9. Specific surface area were calculated for each stations (RES1-8) to which were attributed the calculated diffusive fluxes at each station, taking into account the seasonal variation of the reservoir water surface from the surface-capacity curve (NTPC, 2005).

\subsubsection{Downstream emissions}

Degassing happens downstream of four different structures of the NT2 hydro-system: (1) the Turbines (TRC1), (2) the Regulating Dam $\left(\mathrm{DCH}_{1}\right.$ and NKT3 respectively for the two releases in the Downstream Channel and the Nam Kathang River), (3) the Aeration Weir (DCH3) and (4) the Nakai Dam (NTH3) (Fig. 1, Deshmukh et al., 2016). Additionally, occasional degassing can be observed when water is released at the Nakai Dam through the spillway gates. The amount of $\mathrm{CH}_{4}$ degassed is calculated from the difference between concentrations upstream and downstream of the degassing structures, multiplied by the amount of water discharged (Galy-Lacaux et al., 1997; Deshmukh et al., 2016). Degassing at the turbines is calculated using the average concentrations over the vertical profile at RES9 as upstream concentration, and concentration at TRC1 as the downstream one. Degassing at the regulating dam is calculated using the average concentrations over the vertical profile at REG1 as the upstream value, and the concentrations at $\mathrm{DCH} 1$ and NKT3 as the downstream ones. Upstream concentrations at the aeration weir and the Nakai dam are taken from the surface sampling at $\mathrm{DCH} 2$ and RES1, respectively, when the downstream concentrations come from DCH3 and NTH3 respectively. When necessary, the degassing due to spillway release is computed using the average $\mathrm{CH}_{4}$ concentration in the epilimnion at RES1 (from surface to 
$10 \mathrm{~m}$ depth) as the upstream value, and the surface concentration at NTH3 as the downstream one (Deshmukh et al., 2016).

Downstream emissions can also result from the diffusion of the remaining dissolved methane after water has experienced degassing. Downstream diffusive fluxes are computed from the Thin Boundary Layer (TBL) equation as for the reservoir surface (Eq. 1) based on surface methane concentrations at all the downstream monitoring stations, and a constant $\mathrm{k}_{600}$ of $10 \mathrm{~cm} \mathrm{hr}^{-1}$ as described in Deshmukh et al. (2016). Downstream diffusive fluxes were calculated for four different sections: section 1 from TRC1 to REG1, section 2 from $D C H 1$ to $D C H 2$, and section 3 from $\mathrm{DCH} 3$ to $\mathrm{DCH} 4$ for the Turbines downstream, and section 4 from NTH3 to NTH4 for the Nakai Dam downstream (Fig. 1). Up-scaling of these diffusive fluxes is done by multiplying the surface fluxes (in mmol m $\mathrm{m}^{-2} \mathrm{~d}^{-1}$ ) by the area of the different sections.

\subsubsection{Diffusive fluxes from the drawdown area}

Diffusive fluxes from the drawdown area soils were measured using the static chamber method (Serça et al., 1994). In each investigated site, and after the area was cleared for UXOs (Unexploded Ordnances), four stainless steel collars (surface area $=0.08 \mathrm{~m}^{2}$ ) were inserted in the soil few hours before the flux sampling was performed. Within $45 \mathrm{~min}$, four air samples (in duplicates) were collected with a syringe from the stainless steel chamber butyl stopper at 15 min intervals starting from the initial time when chambers were placed onto the frames. Air samples were transferred into $10-\mathrm{mL}$ glass vials containing $6 \mathrm{M} \mathrm{NaCl}$ solution and capped with butyl stoppers and aluminium seals. All samples were analyzed within $48 \mathrm{~h}$ by GC-FID. Methane fluxes were calculated from the slope of the linear regression of gas concentration in the chamber versus time. This calculation was performed only when the determination coefficient $\left(r^{2}\right)$ of the linear regression was higher than 0.80 . Measurements of diffusive fluxes in the drawdown area conducted during the June 2010 and 2011 field campaigns were done together with soil moisture content and temperature measurements. Sampling strategy intended to investigate both the variety of flooded ecosystems and soil moisture conditions. The investigation of the dependency of fluxes to soil moisture was conducted by measuring along transects from the shoreline to the limit of influence of the reservoir at in each site. Upscaling of emissions from the drawdown was performed at the daily time scale. This was done by calculating the drawdown area from the surfacecapacity curve (NTPC, 2005), and by applying the corresponding specific diffusive flux computed from the flux to soil moisture correlation.

\subsubsection{Statistical analysis}

Spatial variability of diffusive fluxes at the RES1 to RES9 stations and temporal variability between seasons (WD, WW and CD) and years were statistically tested. This was done by using both parametric (Analysis of VarianceANOVA) and non parametric (KruskalWallis) tests in GraphPad Prism 
Cool Dry

(a) RES3

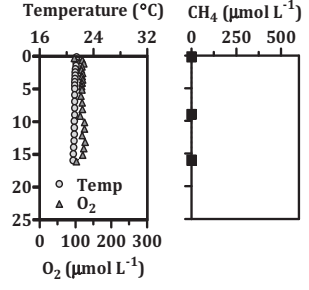

Temperature $\left({ }^{\circ} \mathrm{C}\right) \quad \mathrm{CH}_{4}\left(\mu \mathrm{mol} \mathrm{L}{ }^{-1}\right)$

(b) RES8

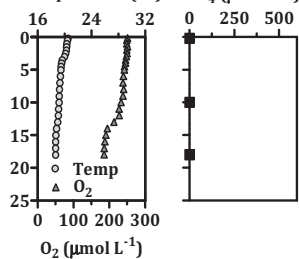

(c) RES9

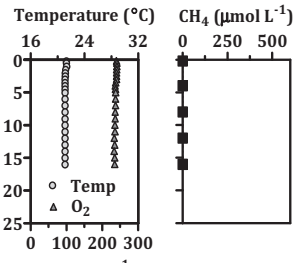

Warm Dry

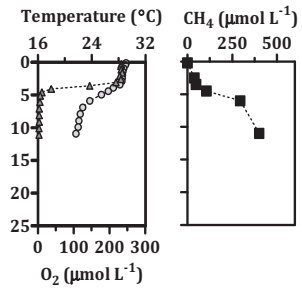

Temperature $\left({ }^{\circ} \mathrm{C}\right) \quad \mathrm{CH}_{4}\left(\mu \mathrm{mol} \mathrm{L}{ }^{-1}\right)$
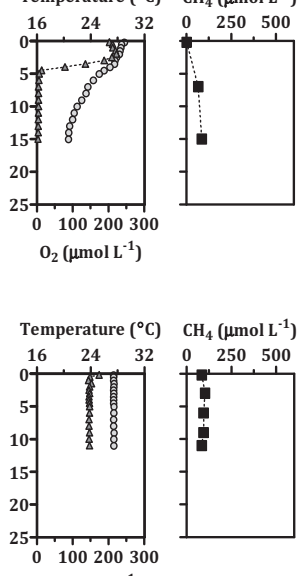

Warm Wet

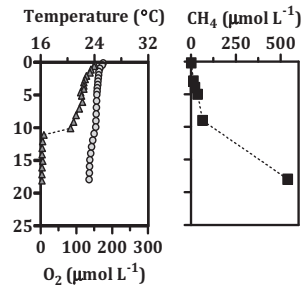

Temperature $\left({ }^{\circ} \mathrm{C}\right) \quad \mathrm{CH}_{4}\left(\mu \mathrm{mol} \mathrm{L}{ }^{-1}\right)$
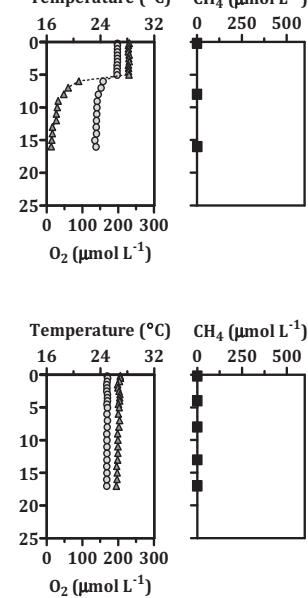

Fig. 2. Evolution of vertical profiles of temperature and oxygen and $\mathrm{CH}_{4}$ concentrations at RES3 (flooded dense forest) (a); RES8 (flooded agricultural lands) (b); RES9 (Water Intake) (c) sampling stations of the NT2 reservoir; representative profiles for the year 2013 are given for each seasons.

Fig. 2. Évolution des profils verticaux de température, oxygène et concentrations de $\mathrm{CH}_{4}$ pour trois stations d'échantillonnage sur le réservoir NT2 ; RES3 (forêt dense inondée) (a), RES8 (zone agricole inondée) (b), et RES9 (prise d'eau) (c) ; des profils représentatifs sont donnés pour chaque saison.

(GraphPad Software, Inc., v5.04) depending on the normal and non-normal behaviour of the tested dataset. All statistical differences were considered with a significance level of $5 \%$.

\section{RESULTS}

\subsection{Vertical profiles and surface concentrations}

RES1 to RES8 stations exhibited a thermically stratified water column from
February to November (Fig. 2). Maximum stratification occurred during the WD season (mid-February to mid-June) when temperature gradient between surface and bottom typically reached $8{ }^{\circ} \mathrm{C}$, and the thermocline, a depth between 4 and $5 \mathrm{~m}$. During the WW season (mid-June to mid-October), monthly mean temperature gradient between the surface and the bottom decreased and stabilized around $6{ }^{\circ} \mathrm{C}$ from July to the end of the season. Occasional sporadic destratification 
events at some stations tended to homogenise temperature in the water column, though surface temperature remained higher than the bottom one. Complete overturn was observed every year during the $C D$ season (mid-October to mid-February) any time from late November to late January (Guérin et al., 2016; Chanudet et al., 2012). Temperature was then constant with depth for periods of a few days or weeks in some of the sampling stations. On a monthly basis, temperature gradient decreased down to $1{ }^{\circ} \mathrm{C}$ after those events in December 2013, a CD season with a particularly weak stratification. RES9 station exhibited all year long a flat profile for temperature, an evidence of the high efficiency of the vortexes to mix the whole water column at the Water Intake.

WD was characterised by an oxicline at a depth comparable to the thermocline (Fig. 2), and almost permanently anoxic hypolimnion. In the $C D$ season, oxygen concentration at the bottom was $>80 \mu \mathrm{mol} \mathrm{L}^{-1}$ during the overturn, a phenomenon particularly intense in 2013 when $\mathrm{O}_{2}$ at the bottom had been consistently higher than the average $\mathrm{O}_{2}$ bottom concentration during the 2010 to 2012 period. Vertical mixing at RES9 insured a permanent $\mathrm{O}_{2}$ penetration throughout the water column with $\mathrm{O}_{2}$ concentration increasing from about $161 \pm 49 \mu \mathrm{mol} \mathrm{L}^{-1}$ in the WD season to $229 \pm 27 \mu \mathrm{mol} \mathrm{L}^{-1}$ in the CD one.

For the RES 1 to RES8 stations, surface $\mathrm{CH}_{4}$ concentration ranged in 2013 from 0.02 to $57.9 \mu \mathrm{mol} \mathrm{L}^{-1}$ all seasons together, with no statistical difference between the stations. $\mathrm{CH}_{4}$ mean concentrations were equal to $2.2 \pm 7.0 \mu \mathrm{mol}$ $\mathrm{L}^{-1}($ median $=0.17), 1.9 \pm 5.8 \mu \mathrm{mol} \mathrm{L}^{-1}$ (median $=0.66$ ) and $1.8 \pm 7.4 \mu \mathrm{mol} \mathrm{L}^{-1}$ (median $=0.35$ ) on average for the $C D$, $W D$ and WW seasons respectively, and were statistically different $(p<0.0001$, Kruskal-Wallis test). For some of the stations located close to some tributaries inflow (RES4, RES7, RES8), occasional extreme surface concentrations were observed during the WW season, a phenomenon also observed in the $C D$ season at stations RES1, RES2 and RES3. During the WD season, $\mathrm{CH}_{4}$ concentrations in the epilimnion and at the surface were consistently lower, by a factor 63 to 95 , than concentrations in the hypolimnion and at the bottom. This factor has decreased when compared to the value of 150 given in Guérin et al. (2016) for the period 2010-2012. This is due to the decrease of $\mathrm{CH}_{4}$ in the hypolimnion, from $265 \pm 279 \mu \mathrm{mol} \mathrm{L}^{-1}$ in 2010, down to $121 \pm 141 \mu \mathrm{mol} \mathrm{L}^{-1}$ in 2013. RES3 station, located in an embayment, was showing consistently higher bottom / hypolimnion concentrations than the other stations, this was particularly true during the WD and WW seasons (Fig. 2). During the WW season, $\mathrm{CH}_{4}$ concentrations as low as $0.01 \mu \mathrm{mol} \mathrm{L}^{-1}$ were found in the vertical profiles of RES7 and RES8, when $\mathrm{CH}_{4}$ concentrations at other stations were similar to those at RES3 (Fig. 2). Concomitantly with the absence of thermal stratification and the high $\mathrm{O}_{2}$ penetration down to the bottom of the reservoir in the $\mathrm{CD}$ season, $\mathrm{CH}_{4}$ bottom concentration gradually dropped down to $1.3 \mathrm{~mol} \mathrm{~L}^{-1}$ in December 2013.

In 2013, RES9 mean vertical profile of $\mathrm{CH}_{4}$ concentration was equal to about $20.2 \pm 17.6 \mu \mathrm{mol} \mathrm{L}^{-1}$ during the WD season and the first two months of the WW season (till mid-August), while 
relatively lower $\mathrm{CH}_{4}$ concentration $\left(0.25 \pm 0.74 \mu \mathrm{mol} \mathrm{L}^{-1}\right)$ was detected for the rest of the year. As the water column was almost perfectly mixed in RES9, seasonal surface concentrations were not much different than the mean seasonal vertical concentration given above. WD and WW mean concentrations were then two orders of magnitude higher than CD mean concentrations with the highest concentrations ( $80 \mu \mathrm{mol} \mathrm{L} \mathrm{L}^{-1}$ ) corresponding to the transition between the WD and WW seasons (June). These seasonal averages were not significantly lower than during the previous years, $(39.8 \pm 48.8$, $29.9 \pm 55.4$ and $1.9 \pm 4.3 \mu^{m o l ~} L^{-1}$ for $W D$, WW and CD respectively for the years 2010-2012; Guérin et al., 2016).

\subsection{Ebullitive fluxes}

Ebullition was found to be statistically different for the three seasons with median fluxes respectively equal to $4.54,8.20$, and $2.91 \mathrm{mmol} \mathrm{m}^{-2} \mathrm{~d}^{-1}$ for the CD, WD and WW seasons $(p<0.0001$, Kruskal-Wallis test, Deshmukh et al., 2014). Modelled and experimental fluxes were the highest in the WD season when total static pressure was decreasing. This decrease was related to both a decrease in atmospheric pressure as well as in hydrostatic pressure, with the water level decreasing at the fastest rate in the WD season. On a yearly basis, and integrated at the reservoir scale, ebullition represented 13.3 $\pm 0.1 \mathrm{Gg}\left(\mathrm{CH}_{4}\right)$ in 2013.

\subsection{Diffusive fluxes}

Fortnightly diffusive fluxes calculated for the year 2013 at RES1 to
RES8 stations ranged from 0.01 to $116.23 \mathrm{mmol} \mathrm{m} \mathrm{m}^{-2} \mathrm{~d}^{-1}$ with an average value of $3.44 \mathrm{mmol} \mathrm{m}^{-2} \mathrm{~d}^{-1}$ (median = $0.59 \mathrm{mmol} \mathrm{m}^{-2} \mathrm{~d}^{-1}$ ). A clear statistical seasonal evolution was detected when comparing the three median seasonal fluxes in $2013(0.19,0.86$, and 0.78 respectively for the $C D, W D$ and WW seasons, $\quad p<0.0001$, Kruskal-Wallis test). Median flux in the WD season was always slightly higher than the median in the WW season, and 4 times higher than the median in the CD season. The presence of a few high fluxes (defined statistically as fluxes higher than $5 \mathrm{mmol} \mathrm{m}^{-2} \mathrm{~d}^{-1}$, see Guérin et al., 2016 for details) during the WD season, particularly at the transition to the WW season (June) as expected from the surface concentrations, and episodically in the CD season, explained those statistics (Guérin et al., 2016, see discussion section). Average flux and range are comparable to values found in tropical reservoirs older than 10 years (Abril et al., 2005; Guérin et al., 2006; Kemenes et al., 2007; Chanudet et al., 2011), while high fluxes rank in the highest values reported for diffusive fluxes in hydroelectric reservoirs or lakes (Bastviken et al., 2011; Barros et al., 2011; Deshmukh et al., 2014; Guérin et al., 2016).

Diffusive fluxes at RES9 in 2013 were as low as $0.03 \mathrm{mmol} \mathrm{m}^{-2} \mathrm{~d}^{-1}$ on some occasions, but also reached more than $230 \mathrm{mmol} \mathrm{m}^{-2} \mathrm{~d}^{-1}$, again a diffusive flux value amongst the highest ever computed for freshwater ecosystem (Guérin et al., 2016). Mean WW and WD season fluxes $\left(39.15 \pm 64.27 \mathrm{mmol} \mathrm{m}^{-2} \mathrm{~d}^{-1}\right.$ and $78.55 \pm 77.28 \mathrm{mmol} \mathrm{m}^{-2} \mathrm{~d}^{-1}$, respectively) were about 100 and 200 times higher than the CD seasons ones $(0.42 \pm$ 


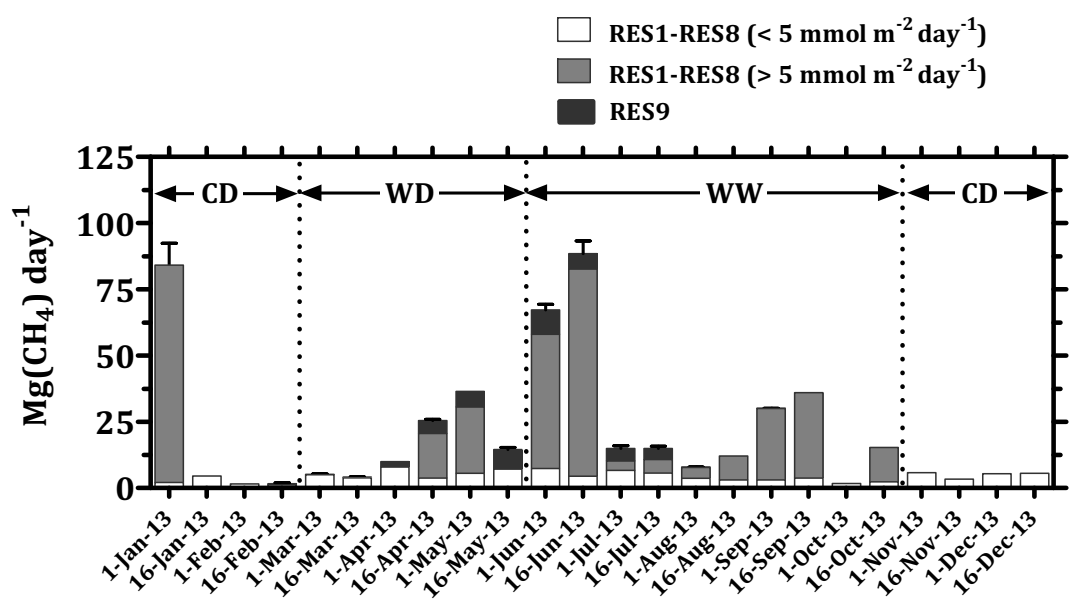

Fig. 3. Mean daily diffusive emissions from the reservoir surface $\left(\mathrm{Mg}\left(\mathrm{CH}_{4}\right)\right.$ day $\left.{ }^{-1}\right)$ calculated fortnightly for the year 2013. Emissions resulting from diffusive fluxes lower than $5 \mathrm{mmol} \mathrm{m}^{-2} \mathrm{~d}^{-1}$ at the RES1-RES8 stations are shown in white, emissions resulting from diffusive fluxes higher than $5 \mathrm{mmol} \mathrm{m}^{-2} \mathrm{~d}^{-1}$ at the RES1-RES8 stations are shown in grey, and emissions at RES9 station (Water Intake) are shown in black. Standard errors on mean daily diffusive emissions are also indicated.

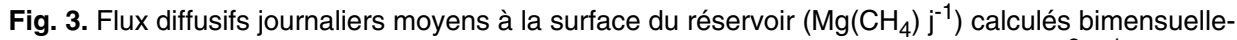
ment pour l'année 2013. Les émissions résultant de flux diffusifs inférieurs à $5 \mathrm{mmol} \mathrm{m}^{-2} \mathrm{~d}^{-1}$ mesurés dans les stations RES1-RES8 sont montrés en blanc, les émissions résultants de flux diffusifs supérieurs à $5 \mathrm{mmol} \mathrm{m}^{-2} \mathrm{~d}^{-1}$ mesurés dans les stations RES1-RES8 sont montrés en gris, les émissions mesurées dans la station RES9 (prise d'eau) sont montrées en noir. Les barres d'erreur sur les flux diffusifs journaliers moyens sont aussi indiquées.

$\left.0.17 \mathrm{mmol} \mathrm{m}^{-2} \mathrm{~d}^{-1}\right)$. Fortnightly emissions were around or above $100 \mathrm{mmol} \mathrm{m}^{-2} \mathrm{~d}^{-1}$ from Mid-April to Mid-July, and occasionally above $200 \mathrm{mmol} \mathrm{m}^{-2} \mathrm{~d}^{-1}$ in June at the transition between WD and WW seasons, when concentrations reached also a maximum in the water column.

With 1.3 and $2.3 \mathrm{Gg}\left(\mathrm{CH}_{4}\right)$ month $^{-1}$ (Fig. 3), January and June 2013 contributed together to about half of the annual diffusive fluxes from the whole reservoir that year. As seen in Figure 3, contribution of high diffusive fluxes $\left(>5 \mathrm{mmol} \mathrm{m}^{-2} \mathrm{~d}^{-1}\right)$ in RES 1 to RES8 stations was the main explanation for these high emissions. All the other fortnightly diffusive fluxes in 2013 were below $0.5 \mathrm{Gg}\left(\mathrm{CH}_{4}\right)$ month $^{-1}$, except for September, with high contributions of diffusion from RES2, RES3 and RES4 stations. On an annual basis, diffusive fluxes higher than $5 \mathrm{mmol} \mathrm{m}^{-2} \mathrm{~d}^{-1}$ at the RES 1 to RES 8 stations contributed to more than $57 \%$ of the total diffusive flux and were dominant. Figure 3 shows that those diffusive fluxes higher than $5 \mathrm{mmol} \mathrm{m}^{-2} \mathrm{~d}^{-1}$ were shaping the seasonal evolution of diffusive fluxes along the year, and could also explain part of the interannual variability (see discussion section). RES9 diffusive emission were mainly concentrated during the WD season and transition to the WW season, and represented about $14 \%$ of the total diffusive fluxes integrated at the reservoir scale. On a yearly basis, and integrated 
at the reservoir scale (RES1 to RES9), diffusive fluxes represented $7.5 \pm 1.2$ $\mathrm{Gg}\left(\mathrm{CH}_{4}\right)$ in 2013.

\subsection{Downstream emissions}

\subsubsection{Degassing}

Among the four structures where permanent degassing can occur, three of them were showing significant release of methane to the atmosphere, excepted Nakai Dam (Fig. 4a). This latter was found to be a negligible source of methane with less than $0.2 \%$ of total methane release from degassing structures. This is due to the small amount of water released there (instream flow = $2 \mathrm{~m}^{3} \mathrm{~s}^{-1}$ ) compared to the maximum $325 \mathrm{~m}^{3} \mathrm{~s}^{-1}$ passing through the turbines (Deshmukh et al., 2016), and to the fact that only surface water with low $\mathrm{CH}_{4}$ content is withdrawn there. This feature was observed in 2013 as well as in the previous years. The highest amount of methane was degassed downstream the aeration weir $(\mathrm{DCH} 3,43 \%$ of total degassed) followed by the degassing downstream of the Regulating Dam (DCH1 and NKT3, total of 35.5\%) and downstream the turbines (TRC1, $22.6 \%$ ). Highest fortnightly degassing was observed during the late WD (May) and at the transition to the WW season (June-July). This is consistent with the highest concentrations in the reservoir, and particularly at RES9, in that period. Degassing during the WD season represented $79 \%$ of the annual 2013 methane degassed, not including the spillway degassing. Degassing during the rest of the year was then of secondary importance if no spillway occurs. Release through the spillway gates always occurs during the WW season when the reservoir reaches its maximal operating level (538 m ASL). Spillway releases were operated in the second half of September and early October 2013 (with 186, 233 and $426 \mathrm{~m}^{3} \mathrm{~s}^{-1}$ fortnightly average flow rate respectively) for a total of $0.48 \pm 0.29$ $\mathrm{Gg}\left(\mathrm{CH}_{4}\right)$ degassed, or $1 / 5$ of the total $2.4 \pm 0.4 \mathrm{Gg}\left(\mathrm{CH}_{4}\right)$ degassed that year. As described in Deshmukh et al. (2016), and considering the results given here for the 2013 degassing, the proportion of methane released from one or the other of these three main permanent degassing structures did not change significantly from one year to the other (regulating dam: $47-55 \%$, aeration weir: $34-39 \%$, turbines: $11-14 \%$ ).

\subsubsection{Diffusion}

Diffusive fluxes ranged between 0.10 and $214 \mathrm{mmol} \mathrm{m}^{-2} \mathrm{~d}^{-1}$ in the section 1 from the turbines (TRC1) to the regulating dam (REG1, Fig. 1, mean = $34.04 \pm 52.4 \mathrm{mmol} \mathrm{m}^{-2} \mathrm{~d}^{-1}$, median $=$ $2.15 \mathrm{mmol} \mathrm{m}^{-2} \mathrm{~d}^{-1}$ ). They ranged between 0.04 and $135 \mathrm{mmol} \mathrm{m}^{-2} \mathrm{~d}^{-1}$ in the sections 2 and 3 of the Downstream Channel (DHC1 to DCH4, Fig. 1, mean $=12.53 \pm 26.0 \mathrm{mmol} \mathrm{m}^{-2} \mathrm{~d}^{-1}$, median $=$ $0.76 \mathrm{mmol} \mathrm{m}^{-2} \mathrm{~d}^{-1}$ ) and in the Nam Kathang River downstream of the regulating dam (NKT3, Fig. 1, mean = $4.49 \pm 16.1 \mathrm{mmol} \mathrm{m}^{-2} \mathrm{~d}^{-1}$, median $=1.01$

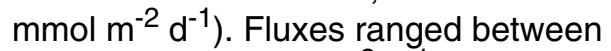
0.07 and $315 \mathrm{mmol} \mathrm{m}^{-2} \mathrm{~d}^{-1}$ in the section 4 (Nam Theun River) downstream of the Nakai dam (NTH3 to NTH4, Fig. 1 , mean $=5.23 \pm 31.0 \mathrm{mmol} \mathrm{m}^{-2} \mathrm{~d}^{-1}$, median $\left.=1.37 \mathrm{mmol} \mathrm{m}^{-2} \mathrm{~d}^{-1}\right)$. $\mathrm{CH}_{4}$ concentrations and fluxes downstream of 

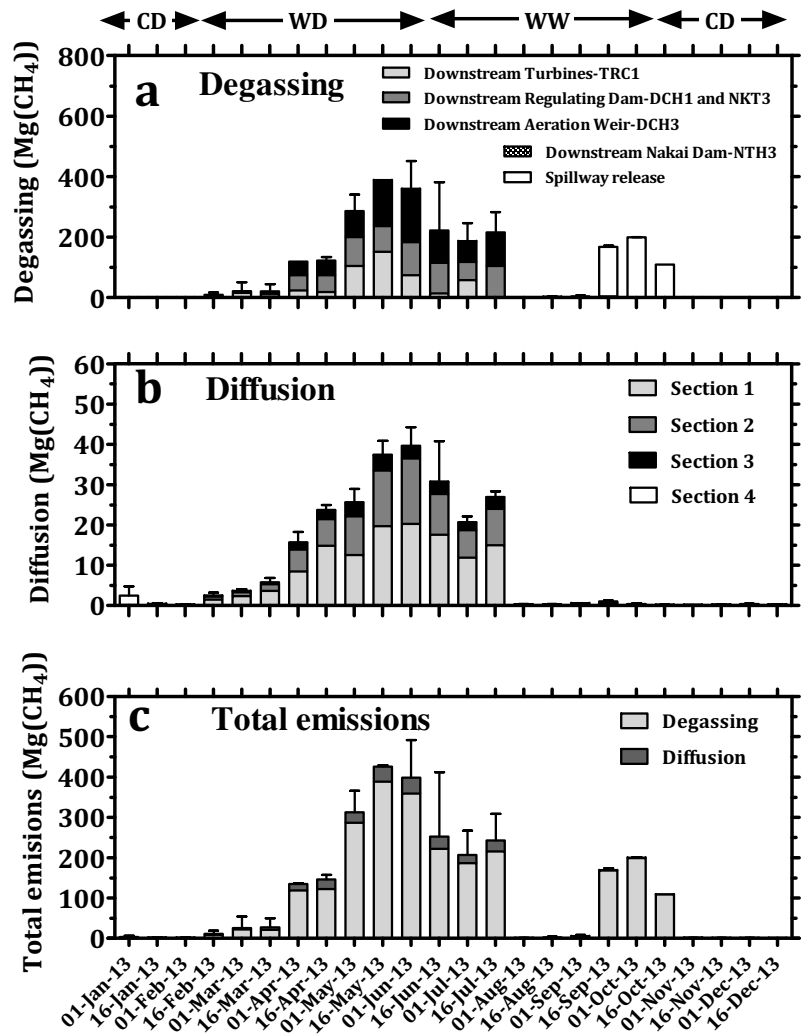

Fig. 4. Fortnightly downstream $\mathrm{CH}_{4}$ emissions $\left(\mathrm{Mg}_{\mathrm{CH}}\right)$ from degassing (a), diffusion (b), and total (c) in year 2013. Note the one order of magnitude difference in the $Y$-axis in panels $a$ and $b$. For diffusive fluxes (b), sections are defined as follow: section 1 from TRC1 to REG1, section 2 from $D C H 1$ to $\mathrm{DCH} 2$, section 3 from $\mathrm{DCH} 3$ to $\mathrm{DCH} 4$, and section 4 from NTH3 to NTH4. Fortnightly standard errors on downstream $\mathrm{CH}_{4}$ emissions are also indicated.

Fig. 4. Émissions aval bimensuelles de $\mathrm{CH}_{4}\left(\mathrm{Mg}_{\mathrm{CH}}\right)$ par dégazage (a), diffusion (b), et totales (c) en 2013. À noter la différence d'ordre de grandeur de l'axe des ordonnées entre les figures a et $b$. Pour les flux diffusifs (b), les sections sont définies comme suit : section 1 de TRC1 à REG1, section 2 de $\mathrm{DCH} 1$ à $\mathrm{DCH} 2$, section 3 de DCH3 à DCH4, et section 4 entre NTH3 et NTH4. Les barres d'erreur sur les émissions aval bimensuelles sont aussi indiquées.

DCH4, as well as downstream NTH4 stations were comparable to the concentrations in the upstream rivers in the same watershed (Deshmukh et al., 2016). As a matter of consequence, no diffusive fluxes attributed to the reservoir were calculated for the section downstream of those two stations.
Diffusive fluxes downstream of the turbines (DCH1 to DCH4 and NKT3 stations) follow the same seasonal variation as those observed for concentrations in the reservoir at RES9. Emissions were the highest in the WD season, intermediate in the WW season, and one order of magnitude lower 
in the CD season for all the sections found downstream of the Turbines. Downstream of the Nakai Dam, low seasonal variability would have been observed in 2013 if high fluxes were not recorded in two occasions $\left(65 \mathrm{mmol} \mathrm{m} \mathrm{m}^{-2} \mathrm{~d}^{-1}\right.$ and $315 \mathrm{mmol} \mathrm{m}^{-2} \mathrm{~d}^{-1}$ on January $13^{\text {th }}$ and December $13^{\text {th }}$ ) making the average CD fluxes 5 times higher than the ones for the two other seasons that year.

Downstream diffusive fluxes decreased with the distance from the release of the water from the reservoir (Fig. 4b), particularly in the Downstream Channel. Mean annual flux decreased from $33.23 \pm 52.36 \mathrm{mmol} \mathrm{m}^{-2} \mathrm{~d}^{-1}$ in the section downstream of TRC1, to $1.28 \pm 2.10 \mathrm{mmol} \mathrm{m}^{-2} \mathrm{~d}^{-1}$ downstream of DHC4 station, almost $28 \mathrm{~km}$ further downstream, a flux typical or even lower than the one observed in the reservoir. The presence of the aeration weir downstream of $\mathrm{DCH} 2$ was efficiently decreasing dissolved $\mathrm{CH}_{4}$ concentration and subsequent diffusive flux by a factor 5 (80\% degassing efficiency, Deshmukh et al., 2016; Descloux et al., $2015 b)$. On a yearly basis, diffusion represented $0.39 \pm 0.01 \mathrm{Gg}\left(\mathrm{CH}_{4}\right)$ in 2013 , with $72 \%$ emitted during the WD season.

\subsection{Drawdown area emissions}

Diffusive fluxes from the drawdown area ranged from -0.43 to $124 \mathrm{mmol} \mathrm{m}^{-2}$ $\mathrm{d}^{-1}$ (soil temperature ranging from 24.4 to $34.7^{\circ} \mathrm{C}$ ). Soil temperature was not found to be any explanatory of the fluxes variability. The type of ecosystem pre-existing to the impoundment was neither a controlling factor for the diffusive $\mathrm{CH}_{4}$ emissions, when on the opposite soil moisture was proved to be a relevant driving parameter. As shown in Figure $5 \mathrm{a}$, with an average flux of $+0.06 \pm 0.20 \mathrm{mmol} \mathrm{m}^{-2} \mathrm{~d}^{-1} 1$, measurement sites with soil moisture from 8 to $40 \%$ were the place of limited $\mathrm{CH}_{4}$ sink or source, with only two significantly higher individual fluxes measured in that soil moisture range. Conversely, measurement sites with soil moisture higher than $40 \%$ were the place of an average emission about four hundred times higher $\left(23 \pm 29 \mathrm{mmol} \mathrm{m}^{-2} \mathrm{~d}^{-1}\right.$, ranging between 0.68 and $124.1 \mathrm{mmol} \mathrm{m}^{-2}$ $\left.\mathrm{d}^{-1}\right)$. The soils with moisture higher than $40 \%$, considered as water-saturated, represented $9.5 \%$ of the drawdown area, which reached a seasonal average $134 \mathrm{~km}^{2}$ in the 2013 WD (Fig. 5b). On an annual basis, those soils covered only $\sim 7 \%$ of the total drawdown area. Applying these annual proportional surfaces to the average fluxes from the two types of soil (lower and higher than 40\% soil moisture), mean area-weighted annual average flux from drawdown soils equals to $1.67 \pm 2.23 \mathrm{mmol} \mathrm{m}^{-2} \mathrm{~d}^{-1}$. This basal emission rate from the drawdown area is four times higher when compared to similar measurements performed in the drawdown area of the Three Gorges Reservoir (0.39 \pm 0.57 $\mathrm{mmol} \mathrm{m}^{-2} \mathrm{~d}^{-1}$; Chen et al., 2011).

Up-scaling of the $\mathrm{CH}_{4}$ fluxes has been done by estimating the surface of the two soil moisture zones from the surface-capacity curve (NTPC, 2005), and assuming a relationship between soil moisture and exposure of soils to air after water level drop in the reservoir. Soils were considered to have a moisture below $40 \%$ when they were exposed to air for more than 10 days, i.e. soils were considered as water-saturated 

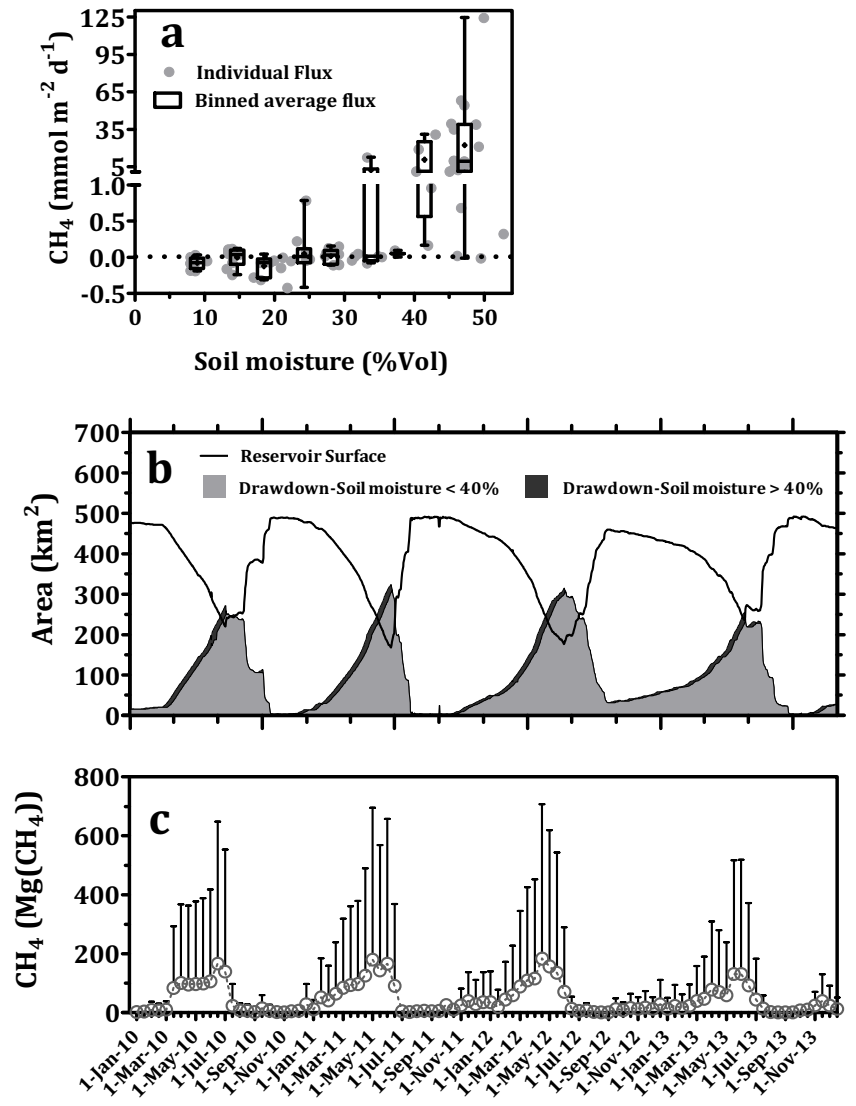

Fig. 5. Individual chamber measurements of $\mathrm{CH}_{4}$ diffusive drawdown emissions and whiskers boxes for binned fluxes (by interval of $5 \%$ soil moisture content) plotted against the soil moisture (a); evolution of the drawdown surface area with soil moisture lower and higher than $40 \%$ together with the reservoir surface for the years 2010 to 2013 (b); Up-scaled drawdown emissions in $\mathrm{Mg}\left(\mathrm{CH}_{4}\right)$ for the years 2010 to 2013 (c).

Fig. 5. Mesures individuelles par chambre des émissions diffusives de $\mathrm{CH}_{4}$ par la zone de marnage et boîtes à moustache des flux moyennés (par intervalle de $5 \%$ en humidité volumique du sol) en fonction de l'humidité des sols (a) ; évolution des surfaces des zones de sol d'humidité inférieure et supérieure à $40 \%$, et de la surface du réservoir entre 2010 et 2013 (b) ; émissions intégrées à l'échelle de toute la zone de marnage en $\mathrm{Mg}\left(\mathrm{CH}_{4}\right)$ pour les années 2010 à 2013 (c).

only when they were exposed to air for less than 10 days. Mean area-weighted average fluxes from the NT2 drawdown are smaller than the diffusion from the water surface, whatever the season considered (from 2.30 to $5.68 \mathrm{mmol} \mathrm{m}^{-2} \mathrm{~d}^{-1}$, respectively for the area weighted fluxes in the CD and WD seasons). This means that drawdown emissions, by surface unit, are two to three times lower than emissions from diffusion by the water surface.

On a yearly basis, and integrated at the reservoir scale, diffusive fluxes from 


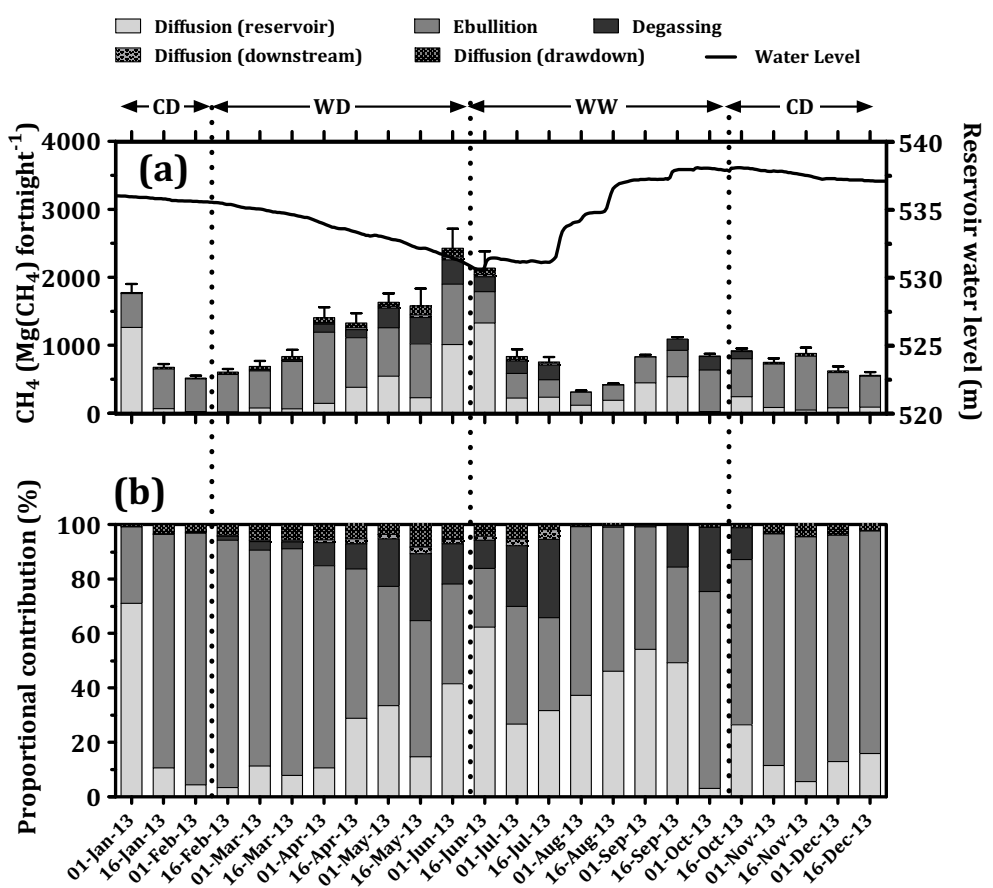

Fig. 6. Fortnightly $\mathrm{CH}_{4}$ emission pathways (bubbling, diffusion from the reservoir surface, diffusion from drawdown area, degassing, and diffusion from downstream) at the NT2 hydro-system for the year 2013 in $\mathrm{Mg}\left(\mathrm{CH}_{4}\right)$ fortnitghly ${ }^{-1}$ (a); proportional contributions (\%) of the different $\mathrm{CH}_{4}$ emission pathways at the NT2 hydro-system in year $2013(\mathrm{~b})$.

Fig. 6. Émissions bimensuelles de $\mathrm{CH}_{4}$ par les différentes voies d'émissions (diffusion par la surface du réservoir, ébullition, dégazage, diffusion aval, et diffusion par la zone de marnage) du système hydro-électrique de NT2 pour l'année 2013 exprimées en $\mathrm{Mg}\left(\mathrm{CH}_{4}\right){ }^{15 j^{-1}}$ (a) ; contributions (\%) des différentes voies d'émission de $\mathrm{CH}_{4}$ par le système hydro-électrique de NT2 en 2013 (b).

the drawdown area represented $0.92 \pm 0.07 \mathrm{Gg}\left(\mathrm{CH}_{4}\right)$ in 2013. With $0.67 \mathrm{Gg}\left(\mathrm{CH}_{4}\right)$ emitted during the four months of the 2013 WD season, that season represented $71 \%$ of the annual emissions.

\section{DISCUSSION}

Figures $6 \mathrm{a}$ and $6 \mathrm{~b}$ show the fortnightly emissions for the year 2013 (respectively in $\mathrm{Mg}\left(\mathrm{CH}_{4}\right)$ fortnightly ${ }^{-1}$, and proportional contribution in \%) in the NT2 hydro-system. As clearly seen from Figure $6 a$, a general feature of the different pathways is the dominance of emissions during the WD season. Depending on the pathway, this dominance is related to different parameters, some linked to management of the NT2 system, when others depend on the hydrology, the climatic conditions (Deshmukh et al., 2016; Guérin et al., 2016), or the surface of the drawdown area as detailed further. Emissions through the ebullition pathway were statistically the highest in the WD season (Fig. 6a). Water level drop and 
atmospheric pressure decrease during that season were both leading to a decrease of the total static pressure (sum of hydrostatic and atmospheric pressures) at the bottom of the water column. Such a decrease triggers the release of methane accumulated in the sediment under the form of bubbles as seen before in NT2 (Deshmukh et al., 2014) or in other freshwater wetlands (Engle \& Melack, 2000), and is able to explain alone $23 \%$ of the ebullition variability. This evidences why the ebullition phenomenon is significantly higher during the WD season, when the water level is decreasing, than during the WW season when the water level is increasing, or during the CD when it is decreasing much more slowly (Deshmukh et al., 2014). With almost 5.9 \pm 0.04 $\mathrm{Gg}\left(\mathrm{CH}_{4}\right)$ emitted during the four months of the 2013 WD season, that season represented $44 \%$ of the annual emissions that year (Deshmukh et al., 2014). This percentage is very constant over time since an average of $47 \%$ of methane was emitted during the WD season for the years 2010-2012. This shows that the predominance of emission during that season is mainly driven by physical parameters which were little prone to changes from one year to the next in the studied period. However, WD season emissions were higher $\left(7.5 \pm 0.04 \mathrm{Gg}\left(\mathrm{CH}_{4}\right)\right)$ in 2010 compared to the years 2011 to 2013 , most likely a consequence of the first water level drop following the turbine commissioning in March of that year which released methane accumulated since the impoundment (full level first reached in October 2009). It is more than likely that the production of $\mathrm{CH}_{4}$ in the sediment was also higher that year, the first after impoundment.

Emissions through ebullition also remained remarkably constant over the years with an average yearly emission integrated at the reservoir scale of $13.8 \pm 0.18 \mathrm{Gg}\left(\mathrm{CH}_{4}\right)$ for the period 2010 to 2012 , and $13.3 \pm 0.1 \mathrm{Gg}\left(\mathrm{CH}_{4}\right)$ emitted in 2013. High amount of methane accumulated at the sediment-water interface could have led to strong ebullition in 2010. This was somehow counterbalanced by the constant water level during the first months of 2010 before commissioning, leading to a total of $14.4 \mathrm{Gg}\left(\mathrm{CH}_{4}\right)$ released that year. The stability of ebullition emissions was also observed all along the 2009 to 2013 field campaigns used to train the ANN model (Deshmukh et al., 2014). Should the emissions by ebullition be decreasing in the future years, a new ANN model would need to be trained including this decrease. For the four years since commissioning, ebullition had always been the dominant emission pathway for the NT2 hydro-system in absolute (from 13.3 to $14.7 \mathrm{Gg}\left(\mathrm{CH}_{4}\right)$ year $^{-1}$ ) and relative (from 40 to $67 \%$ ) values (Fig. 6b and 7). Such high percentages were never reported in other hydro-reservoirs. They are about two times higher than the percentages found in Petit Saut (Abril et al., 2005), but with comparable emitted quantities (in $\mathrm{Gg}\left(\mathrm{CH}_{4}\right)$ year $^{-1}$ ). These higher than usual percentages might come partly from the careful sampling set up to investigate that specific pathway, and partly to the particularly large areas of shallow depth and flat bottom in the South West part of the reservoir, as well as to the strong yearly change in water 


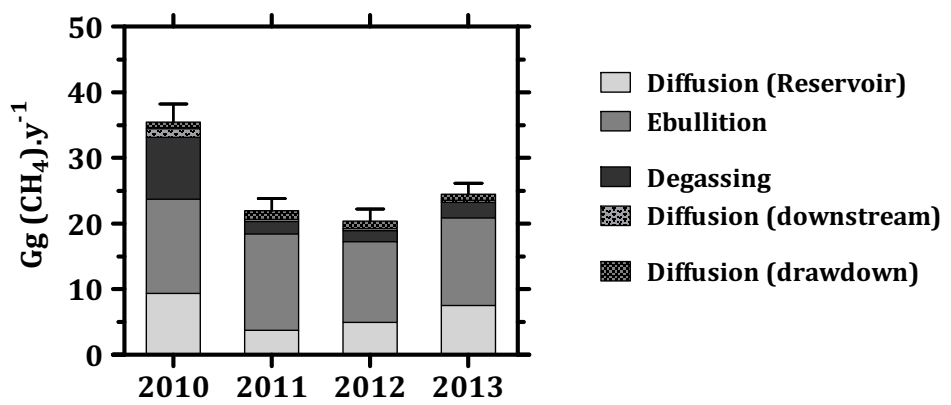

Fig. 7. Total emissions for the years 2010 to 2013 for the different pathways. Annual standard errors are also indicated.

Fig. 7. Totaux des différentes voies d'émissions pour les années 2010 à 2013. Les barres d'erreur sur les émissions annuelles sont aussi indiquées.

depth (up to $9 \mathrm{~m}$ ). They are also related to the high $\mathrm{CH}_{4}$ diffusion and oxidation at the Water Intake, and to the subsequent low downstream emissions.

As seen in Figure 3 , contribution of high diffusive fluxes $\left(>5 \mathrm{mmol} \mathrm{m}^{-2} \mathrm{~d}^{-1}\right)$ in RES1 to RES8 stations was the main explanation for high emissions in January and June 2013. These high emissions were both the consequence of an overturn in January, releasing methane accumulated since the beginning of the CD season, and of some sporadic destratification events observed in June. Secondary high cumulated emissions in September were correlated to some sporadic destratification events which occurred that month at RES2, RES3 and RES4 stations.

The seasonal evolution evidenced in 2013 for the RES 1 to RES 8 stations was a feature already found for the years 2010 to 2012 (median $=0.19$, $1.09,0.59 \mathrm{mmol} \mathrm{m}^{-2} \mathrm{~d}^{-1}$, respectively for the CD, WD and WW seasons, $p<0.0001$, Kruskal-Wallis test, Guérin et al., 2016). As expected from the concentration evolution at RES1 to RES8 stations, no interannual tendency was evidenced for the 2010 to 2013 flux time series. Median RES1 to RES8 fluxes decreased from $0.66 \mathrm{mmol} \mathrm{m}^{-2} \mathrm{~d}^{-1}$ in 2010 to $0.51 \mathrm{mmol} \mathrm{m}^{-2} \mathrm{~d}^{-1}$ in 2011 , before raising to $0.55 \mathrm{mmol} \mathrm{m}^{-2} \mathrm{~d}^{-1}$ and $0.59 \mathrm{mmol} \mathrm{m}^{-2} \mathrm{~d}^{-1}$ in 2012 and 2013 respectively, all fluctuations being statistically non-significant ( $p=0.4679$, Kruskal-Wallis test). Diffusive fluxes at RES9 station were mainly concentrated during the WD season and transition to the WW season (Guérin et al., 2016). RES9 diffusive fluxes for the WD season were constant for the year 2013 when compared to the previous years, when average emissions of the WW and $C D$ seasons had been divided in 2013 by a factor 2 and 5 respectively compared to what they were the years before, though median remained remarkably constant (around 1.2 and $0.4 \mathrm{mmol} \mathrm{m}^{-2} \mathrm{~d}^{-1}$ respectively for the $W W$ and $C D$ seasons). Maximum diffusive fluxes at RES9 decreased from more than $600 \mathrm{mmol} \mathrm{m}^{-2} \mathrm{~d}^{-1}$ in 2010 (Guérin et al., 2016) to about $230 \mathrm{mmol}$ $\mathrm{m}^{-2} \mathrm{~d}^{-1}$ in 2013, while average emissions decreased by a factor of three to annual average $50 \mathrm{mmol} \mathrm{m}^{-2} \mathrm{~d}^{-1}$ from 
2010 to 2013. However, as for the RES1 to RES8 stations, diffusive fluxes at RES9 showed no interannual variation ( $p=0.054$, Kruskal-Wallis test). RES9 diffusive fluxes represented about $14 \%$ of the total diffusive fluxes integrated at the reservoir scale in 2013, after representing up to $25 \%$ of the annual emission in 2010. On a yearly basis, and integrated at the reservoir scale (RES1 to RES9), diffusive fluxes showed no statistical difference $(p=0.3613$, Kruskal-Wallis test) from 2010 to 2013 (Fig. $6 \mathrm{~b}$ and 7). Diffusion from the reservoir surface had always been the second pathway by order of importance, except in 2010 when degassing was slightly higher $\left(9.5 \mathrm{Gg}\left(\mathrm{CH}_{4}\right)\right.$ year $\left.{ }^{-1}\right)$. It has been shown that the presence of high fluxes $\left(>5 \mathrm{mmol} \mathrm{m}^{-2} \mathrm{~d}^{-1}\right)$ during the WD season, or in June at the transition to the WW season, were linked to the reservoir hydrodynamics (sporadic destratification events), leading to high cumulated release of methane (Guérin et al., 2016). More frequent sporadic destratification events were observed in the WD seasons of 2011 and 2013 with diffusive emissions higher than $50 \%$ of the total emissions in the second half of June 2013 (Fig. 6b). Higher fluxes were also recorded later during the $2013 \mathrm{WW}$ season with sporadic destratification events in September. Overturn must have been the strongest during the 2012 CD season as well as during the first half of January 2013. On the opposite, there was no $\mathrm{CH}_{4}$ accumulated in the water column to be released in the 2011 CD season overturn. Higher than average diffusive fluxes in the WW season of 2010 were the consequence of the accumulation of water from May
2008 to March 2010 (residence time $>700$ days). $2010 \mathrm{WW}$ season was also the period when the highest amount of OM was available for mineralization in the water column boosting the $\mathrm{CH}_{4}$ production (Guérin et al., 2016). Diffusion represented roughly a $1 / 4$ of the mean total emissions, a proportion higher than observed in Petit Saut, not including the first year after commissioning, though with an average $6.4 \mathrm{Gg}\left(\mathrm{CH}_{4}\right)$ year ${ }^{-1}$ emitted between 2010 and 2013, this pathway is comparable in absolute value to the diffusive emissions reported for Petit Saut three years after impoundment (Abril et al., 2005).

Seasonal variation was well marked for the degassing emission pathway. Most of the methane, if not all, was emitted by degassing and/or oxidized at the permanent degassing structures during the WD season and first month of the WW one (Deshmukh et al., 2016). This is consistent with the seasonality of $\mathrm{CH}_{4}$ concentration at the Water Intake. The seasonal pattern was only altered if spillway releases are conducted, like in 2013, with three significant releases between the end of September and the beginning of October. For the years 2010-2012, integrated for the four degassing structures, and including spillway, degassing on a yearly basis represented $9.5 \pm 0.8,2.0 \pm 0.4,1.7 \pm 0.3$ and $2.4 \pm 0.4 \mathrm{Gg}\left(\mathrm{CH}_{4}\right)$ year ${ }^{-1}$ respectively from 2010 to 2013 (Fig. 7), corresponding to a statistically significant decrease with years $(p=0.0038$, ANOVA test).

With a mean $3.9 \mathrm{Gg}\left(\mathrm{CH}_{4}\right)$ year ${ }^{-1}$, degassing had always been the third pathway in the NT2 hydro-system, 
representing $1 / 8$ of the mean total emissions for the period 2010 to 2013. Degassing is significantly reduced in the NT2 hydro-system compared to similar sub-tropical or tropical reservoirs (Deshmukh et al., 2016). As a comparison, degassing was representing about $15.3 \mathrm{Gg}\left(\mathrm{CH}_{4}\right)$ year $^{-1}$ at Petit Saut four years after impoundment (Abril et al., 2005), or $70 \%$ of the total emissions that year (same pathways accounted for as in NT2, except the drawdown area one). It has been shown that the reduced degassing observed in NT2 was due to the strong vertical mixing of the water column at the Water Intake (RES9). This favours a high $\mathrm{CH}_{4}$ emission at that spot (Guérin et al., 2016), with emissions representing, depending on the years, from $9.9 \%$ to $24.9 \%$ of the diffusion emissions integrated at the reservoir surface. Mixing also favours $\mathrm{CH}_{4}$ oxidation. This would prevent the release of $2.1 \mathrm{Gg}\left(\mathrm{CH}_{4}\right)$ year $^{-1}$, or about $50 \%$ of the methane effectively emitted by degassing (mean 2010-2013 value) to the atmosphere, a specific feature of the NT2 hydro-reservoir (Descloux et al., 2015b; Deshmukh et al., 2016).

With higher emissions during the WD season, diffusion downstream showed a seasonality comparable to the other pathways, and particularly to degassing, but only in the Downstream Channel section. Indeed, diffusion is then proportional to the water passing to the turbines from the Water Intake which also shows a very strong seasonal variation with higher methane dissolved in the water during the WD season, and lower one in the CD season (Deshmukh et al., 2016). The figure is different downstream the Nakai dam.
Surface water release from RES1 (Fig. 1) to the Nam Theun River to sustain the instream flow is showing little seasonal variation at the NTH3 station and further downstream (Fig. 1), except with the case of a few releases of surface water with enhanced methane concentration in the reservoir due to CD overturn. No such events were observed in 2013, and since the degassing at the Nakai dam is negligible, the total diffusion for both downstream systems shows a seasonal variability driven by the seasonality in the Downstream Channel section, with 3/4 of the emissions occurring during the WD season. Emissions in the WD season represented $72 \%$ in 2013 , a percentage relatively constant for the last four years with a value of $76 \%$ from 2010 to 2013 . Percentage was notably smaller in $2010(67 \%)$ because of 8 to 10 times higher WW emissions $\left(0.43 \mathrm{Gg}\left(\mathrm{CH}_{4}\right)\right)$ that year. This is another expression of the higher methane concentration in the reservoir in 2010 after a year and a half without turbine release (Deshmukh et al., 2016). When compared to degassing, downstream diffusion on a yearly basis represented from $14 \%$ (2010) to about 20\% (2012) of the total downstream emissions (average 2010-2013 $=15.5 \%$ ). Percentage was the lowest in 2010 when degassing was particularly important both from spillways and normal operating release, and the highest in 2012, when no spillway occurred.

On a yearly basis, diffusion downstream represented $0.39 \pm 0.01 \mathrm{Gg}\left(\mathrm{CH}_{4}\right)$ in 2013, after $1.33 \pm 0.01,0.32 \pm 0.01$ and $0.33 \pm 0.01 \mathrm{Gg}\left(\mathrm{CH}_{4}\right)$ respectively from 2010 to 2012 (Fig. 7), showing a statistically significant decrease $(p=0.0134$, ANOVA test) with years. With a mean 
annual $0.55 \mathrm{Gg}\left(\mathrm{CH}_{4}\right)$ emitted, diffusion downstream represented an average $2 \%$ of the total emissions, and remained a pathway of secondary importance during the four years of the study.

Higher emissions methane emissions in soils with moisture higher than $40 \%$ is a phenomenon consistent with higher methanogenesis and lower diffusion of $\mathrm{O}_{2}$ and subsequent methanotrophy in those soils (Dalal et al., 2008; Serrano-Silva et al., 2014). As for the previously described pathways, diffusive emissions from the drawdown area were also higher during the WD season, here a consequence of the highest extent of the drawdown area during that season. With $0.67 \mathrm{Gg}\left(\mathrm{CH}_{4}\right)$ emitted during the four months of the $2013 \mathrm{WD}$ season, that season represented $71 \%$ of the annual emissions, i.e., a percentage very constant over time (an average $74 \%$ of methane was emitted during the WD season for the years 20102012). Since no seasonal variation was applied to the specific emission rate used to up-scale the emissions from soils with moisture below or above $40 \%$, this seasonality is only driven by the area of the whole drawdown, and by the proportional fraction of water-saturated soils uncovered during that season. CD is the season when the drawdown starts to stretch (reaching $34 \mathrm{~km}^{2}$ at the end of that season), and as a consequence, emissions during that season represented $20 \%$ of the annual emissions (year 2013). With $5 \%$ of annual emission in 2013, emissions occurring in the WW season, when the reservoir stays most of the time at its highest operation level, were of secondary importance. The drawdown area acted as a constant source of $\mathrm{CH}_{4}$ with emissions remaining more or less constant over the years (from 0.92 to $1.30 \mathrm{Gg}\left(\mathrm{CH}_{4}\right)$ year ${ }^{-1}$; Fig. 7). Given the approach conducted here where no interannual variability was applied to the specific fluxes from the drawdown fluxes, this means that the drawdown surface area used to up-scale specific diffusive fluxes from the drawdown soils has seen little interannual variability during that period, except for the year 2010. Emissions from the drawdown, which are proportional to the drawdown surface area, were reduced before the commissioning in March 2010, with a reduced surface of the drawdown area of $37 \mathrm{~km}^{2}$ compared to an average $89 \mathrm{~km}^{2}$ at the same period of the years 2011 to 2013 . With a mean annual $1.1 \mathrm{Gg}\left(\mathrm{CH}_{4}\right)$ emitted for the four studied years, drawdown emissions represented an average $4.5 \%$ of the total annual emissions. Even if the NT2 hydro-system presents a large drawdown area in the CD and WD seasons, this pathway remained of secondary importance.

All in one, the three months of the WD season (March to May) have been representing $43 \%$ of the total annual 2013 emissions. This percentage is the lowest since commissioning, WD season being on average over the 2010 to 2013 period totalling about $50 \%$ of the emissions. Percentage is smaller in 2013 because of the strong release from the CD season overturn, and during WW season destratification events (September) and spillway releases (September-October). The mean seasonal feature can be altered with higher than average emissions if one or several of the following conditions are encountered: i) overturn during the $C D$ releasing large amounts of methane 
accumulated in the water column like in 2012 and 2013, ii) sporadic destratification events in the WW season like in 2013, iii) spillway releases like in 2010 (responsible of more than $40 \%$ of the degassing) and 2013, and iv) artificially enhanced diffusion because of accumulated methane in the water due to management (like in 2010). On the opposite, other phenomena, linked to hydrology for example, can also lead to lower emissions in some periods. One should note that all of the overturns do not lead necessary to enhanced emissions. This was the case for example in 2011 because of the low $\mathrm{CH}_{4}$ accumulated in the water column that year. 2011 was indeed a year with higher than normal precipitation records which might have facilitated the $\mathrm{O}_{2}$ penetration in the water column and the subsequent oxidation of $\mathrm{CH}_{4}$ (Guérin et al., 2016). Reduced residence time and increased water renewal were also consequences of these higher precipitations, both factors favouring lower $\mathrm{CH}_{4}$ concentrations in the reservoir. Ebullition pathway has been showing little change over the years so far. This is because the main driver of those emissions, the change in the water level, has not changed much from year to the other so far (except 2010). As a matter of consequences, the drawdown emissions, also depending on the fluctuations of the water level and the subsequent drawdown area have been remarkably constant since commissioning ( $p=0.8107$, ANOVA test), though part of the interannual variability might have been overlooked since a constant specific diffusive emission was applied for the four years after commissioning.

If percentages of emission from the different pathways have changed along the four years of the study as discussed above, the upstream emissions (diffusion from the reservoir, ebullition and emissions from the drawdown) have always been dominant. Due to the higher than average degassing in 2010, upstream emissions represented about $2 / 3$ that year, when this percentage reached $90 \%$ from 2011 to 2013 . This percentage is much higher than in other reservoirs (Abril et al., 2005; Teodoru et al., 2015). The upstream to downstream ratio started to be lower than $50 \%$ after three years in Petit Saut, and kept decreasing in the following years (Abril et al., 2005). Higher percentage in the NT2 hydro-system is due to the transfer of a large part of the emissions occurring downstream in other reservoirs (degassing and diffusion) to the upstream where high diffusion at the Water Intake takes place. Emissions from the drawdown area, even if they represent in average less than $5 \%$ of the total emissions, are also contributing to higher upstream to downstream ratio in the NT2 hydro-system.

Figure 7 gives the total gross methane emissions (in $\mathrm{Gg}\left(\mathrm{CH}_{4}\right)$ year $^{-1}$ ) from the NT2 reservoir for the years 2010 to 2013. Emission have been the highest in $2010\left(35.6 \pm 2.6 \mathrm{Gg}\left(\mathrm{CH}_{4}\right)\right.$ year $\left.^{-1}\right)$, then dropped in $2011\left(22.0 \pm 1.4 \mathrm{Gg}\left(\mathrm{CH}_{4}\right)\right.$ year $\left.^{-1}\right)$ and $2012\left(20.4 \pm 1.5 \mathrm{Gg}\left(\mathrm{CH}_{4}\right)\right.$ year $\left.^{-1}\right)$, before slightly increasing in 2013

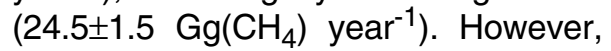
the difference is not quite statistically significant $(p=0.0761$, Kruskal-Wallis 
test). This means that the tendency to the emission decrease, if apparently started, is not yet significant. As detailed before, different parameters, either from the reservoir hydrodynamics or the hydrology are shaping the emissions not only at the seasonal but also annual scale. The lack of clear significant decrease of the total gross emission evolution is not surprising when one gets in mind that ebullition and diffusion pathways, responsible of about $3 / 4$ of the emissions since impoundment, show no or little evolution in the four years $(p=0.6972$, ANOVA test, and $p=$ 0.3613 , Kruskal-Wallis test, respectively). Average annual $\mathrm{CH}_{4}$ emitted during the 4 years (2010-2013) after commissioning equals to $25.6 \pm 3.3$ $\mathrm{Gg}\left(\mathrm{CH}_{4}\right)$ year $^{-1}$. This amount is about twice smaller than the total emissions (excluding emissions from drawdown area) estimated in the only comparable (in terms of comprehensive study and climatic conditions) hydro-reservoir of Petit Saut (French Guiana) for the four years following commissioning (average $54.78 \mathrm{Gg}\left(\mathrm{CH}_{4}\right)$ year $^{-1}$, Abril et al., 2005). The decrease in amount of flooded carbon available for mineralization and gaseous emissions of methane will eventually happen in the coming years. Petit Saut Reservoir total methane emissions have been divided by a factor 8.5 within the ten first years after commissioning. Applying this factor to Nam Theun would mean that emissions would drop from $34.6 \mathrm{Gg}\left(\mathrm{CH}_{4}\right)$ year ${ }^{-1}$ (all emissions but drawdown emissions) from 2010 to about $4 \mathrm{Gg}\left(\mathrm{CH}_{4}\right)$ year ${ }^{-1}$ ten years latter.

\section{CONCLUSION}

This study is one of the very few to present an assessment of the comprehensive methane emission pathways, including the drawdown area, for a hydro-reservoir system. Total methane emissions in the NT2 hydro-system are lower than in the comparable Petit Saut Reservoir by a factor two at the same age. Repartition between the pathways is markedly different, with a much higher proportion of methane emitted upstream in NT2. This could be due to the careful survey undertaken to study the ebullition pathway that might have emphasized the emission normally attributed to this pathway. It is more likely due to the design of the NT2 hydro-system. This one might have favoured ebullition from the large proportions of flat-bottom shallow areas. Man-made Water Intake design also favours the diffusion there, as well as the oxidation of methane. Water management since impoundment is responsible of higher total emissions in 2010 due to the favourable conditions for the production of methane in the stagnant water after impoundment, and to the sudden release with commissioning. Spillway is another water management that can also be responsible to enhanced emissions in given years, e.g. 2010 and 2013. Evolution of the drawdown area along the seasons, as a result from the water management, also affects the methane budget of the NT2 area by minimizing the total emissions with lower emissions from the drawdown soils compared to the diffusive 
fluxes from the water surface. Others parameters playing a role in the total methane emissions are linked to proper behaviour of the water body under the influence of hydrology and hydrodynamics. This includes destratification events, overturn, oxygen penetration and methane oxidation. These phenomena all together have been modulating the total emission one year to the other by giving different weights to the different pathways, with enhanced emissions in 2010, and more secondarily in 2013 , and possibility minimized ones in 2011 and 2012. All methane emission pathways will continue to decrease with the decreasing available carbon to fuel the emissions, but not in a monotonous way as seen during these four years. There are no clues as regards to the evolution of the drawdown emissions on the longer term. It is clear that the surface of the drawdown area should not undergo strong evolution in the future since it is closely linked to the electricity production and reservoir management. In terms of emission intensity, it will mostly depend on the evolution of the carbon cycle in that area. Succession of flooded and drying-out periods is a well-known process able to enhance the decomposition of the organic matter present in the soils. Carbon cycle could be modified both by natural processes (vegetation regrowth) and/or artificial management (crops and grazing for example). Vegetation re-growth in that area, whether of natural origin or linked to human practices, could help in maintaining carbon pool present in these soils and their potential to emit methane.

\section{ACKNOWLEDGMENTS}

This research was conducted at the Aquatic Environment Laboratory of Nam Theun 2 Power Company in Lao PDR whose Shareholders are Électricité de France, Lao Holding State Enterprise and Electricity Generating Public Company Limited of Thailand. The authors would like to thank the Nam Theun 2 Power Company (NTPC) for providing the logistic support on site related to field activities. We are also grateful to all the members, management and staff, of the Aquatic Environment Laboratory (AEL) of the Nam Theun 2 project for the continuous sampling and analysis in the framework of the environmental monitoring programme. C. Deshmukh benefited from a PhD grant from Électricité de France.

\section{REFERENCES}

Abril G., Guérin F., Richard S., Delmas R., Galy-Lacaux C., Gosse P., Tremblay A., Varfalvy L., Dos Santos M.A. \& Matvienko B., 2005. Carbon dioxide and methane emissions and the carbon budget of a 10-year old tropical reservoir (Petit Saut, French Guiana). Global Biogeochem. Cycles 19, GB4007, doi:10.1029/2005GB002457.

Abril G., Commarieu M.V. \& Guérin F., 2007. Enhanced methane oxidation in an estuarine turbidity maximum. Limnol. Oceanogr. 52 : 470-475.

Barros N., Cole J.J., Tranvik L.J., Prairie Y.T., Bastviken D., del Giorgio P., Roland F. \& Huszar V., 2011. Carbon emission from hydroelectric reservoirs linked to reservoir age and latitude. Nat. Geosci. 4 : 593-596. 
Bastviken D., Tranvik L.J., Downing J.A., Crill P. M. \& Enrich-Prast A., 2011. Freshwater methane emissions offset the continental carbon sink. Science 331:50.

Chanudet V., Descloux S. Harby A., Sundt H., Hansen B.H., Brakstad O., Serça D. \& Guérin F., 2011. Annual gross $\mathrm{CO}_{2}$ and $\mathrm{CH}_{4}$ emissions and carbon budget of the Nam Ngum and Nam Leuk subtropical Reservoirs in Lao PDR. Science of the Total Environment 409 : 5382-5391.

Chanudet V., Fabre V. \& van der Kaaij T., 2012. Application of a three-dimensional hydrodynamic model to the Nam Theun 2 Reservoir (Lao PDR). Journal of Great Lakes Research 38 : 260-269, http://dx.doi.org/10.1016/ j.jglr.2012.01.008.

Chen H., Wu Y., Yuan X., Gao Y., Wu N. \& Zhu D., 2009. Methane emissions from newly created marshes in the drawdown area of the Three Gorges Reservoir. J. Geophys. Res. 114 : D18301, doi:10.1029/ 2009JD012410.

Chen H., Yuan X.Z., Chen Z.L., Wu Y.Y., Liu X.S., Zhu D., Wu N., Zhu Q., Peng C.H. \& LiW.Z., 2011. Methane emissions from the surface of the Three Gorges Reservoir. J. Geophys. Res.116:D21306.

Dalal R.C., Allen D.E., Livesley S.J. \& Richards G., 2008. Magnitude and biophysical regulators of methane emission and consumption in the Australian agricultural, forest, and submerged landscapes: a review. Plant and Soil $309:$ 43-76.

DelSontro T., McGinnis D.F., Sobek S., Ostrovsky I. \& Wehrli B., 2010. Extreme Methane Emissions from a Swiss Hydropower Reservoir: Contribution from Bubbling Sediments. Environmental Science \& Technology 44 : 24192425, doi: $10.1021 /$ es9031369.

DelSontro T., Kunz M.J., Kempter T., Wüest A., Wehrli B. \& Senn D.B., 2011. Spatial heterogeneity of methane ebullition in a large tropical reservoir. Environ. Sci. Technol. 45 : 9866-9873.

Descloux S., Chanudet V., Poilvé H. \& Grégoire A., 2011. Coassessment of biomass and soil organic carbon stocks in a future reservoir area located in Southeast Asia. Environ. Monit. Assess. $173:$ 723-741.

Descloux S., Guedant P., Phommachanh D. \& Luthi R., 2016a. Main features of the Nam Theun 2 hydroelectric project (Lao PDR) and the associated environmental monitoring programme. Hydroécol. Appl. 19 (same issue).

Descloux S., Chanudet V., Taquet B., Rode W., Guédant P., Serça D., Deshmukh C. \& Guerin F., 2016b. Efficiency of the Nam Theun 2 hydraulic structures on water aeration and methane degassing. hydroécol. Appl. 19 (same issue).

Deshmukh C., Serça D. Delon C., Tardif R., Demarty M., Chanudet V., Guédant P., Rode W., Descloux S. \& Guérin F., 2014. Physical controls on $\mathrm{CH}_{4}$ emissions from a newly flooded subtropical freshwater hydroelectric reservoir: Nam Theun 2. Biogeosciences 11 : 42514269, doi:10.5194/bg-11-4251.

Deshmukh C., Guérin F., Pighini S., Vongkhamsao A., Guédant P., Rode W., Godon A., Chanudet V., Descloux S. \& Serça D., 2016. Low methane $\left(\mathrm{CH}_{4}\right)$ emissions downstream of a newly flooded subtropical hydroelectric reservoir (Nam Theun 2, Lao PDR), Biogeosciences, under review.

Engle D. \& Melack J.M., 2000. Methane emissions from an Amazon floodplain lake: Enhanced release during episodic mixing and during falling water. Biogeochemistry $51:$ 71-90.

Galy-Lacaux C., Delmas R., Jambert C., Dumestre J.F., Labroue L., Richard S. \& Gosse, P., 1997. Gaseous emissions and oxygen consumption in hydroelectric dams: A case study in French Guiana. Global Biogeochem. Cycles 11 : 471-483. 
Guérin F. \& Abril G., 2007. Significance of pelagic aerobic methane oxidation in the methane and carbon budget of a tropical reservoir. J. Geophys. Res.-Biogeo. 112 : G03006, doi:10.1029/2006JG000393.

Guérin F., Abril G., Richard S., Burban B., Reynouard C., Seyler P. \& Delmas R., 2006. Methane and carbon dioxide emissions from tropical reservoirs: significance of downstream rivers. Geophys. Res. Lett. 33 : L21407.

Guérin F., Abril G., Serça D., Delon C., Richard S., Delma, R., Tremblay A. \& Varfalvy L., 2007. Gas transfer velocities of $\mathrm{CO}_{2}$ and $\mathrm{CH}_{4}$ in a tropical reservoir and its river downstream. J. Mar. Syst. $66: 161-172$

Guérin F., Abril G., de Junet A. \& Bonnet M.P., 2008. Anaerobic decomposition of tropical soils and plant material: Implication for the $\mathrm{CO}_{2}$ and $\mathrm{CH}_{4}$ budget of the Petit Saut Reservoir. Applied Geochemistry 23 : 2272-2283.

Guérin F., Deshmukh C., Labat D., Pighini S., Vongkhamsao A., GuédantP., RodeW., Godon A., Chanudet V., Descloux S. \& Serça D., 2016, Effect of sporadic destratification, seasonal overturn and artificial mixing on $\mathrm{CH} 4$ emissions at the surface of a subtropical hydroelectric reservoir (Nam Theun 2 Reservoir, Lao PDR), Biogeosciences, under review.

IPCC: Summary for Policymakers, in: Climate Change 2013: The Physical Science Basis. Contribution of Working Group I to the Fifth Assessment Report of the Intergovernmental Panel on Climate Change. In: Stocker T.F., Qin D., Plattner G.-K., Tignor M., Allen S.K., Boschung J., Nauels A., Xia Y., Bex V. \& Midgley P.M. (Eds.), Cambridge University Press, Cambridge, United Kingdom and New York, NY, USA.

Jähne B., Munnich K.O., Bosinger R., Dutzi A., Huber W. \& Libner P., 1987.
On parameters influencing air-water exchange. J. Geophys. Res. 92 : 19371949.

Kemenes M., Forsberg B.R. \& Melack J.M., 2007. Methane release below a tropical hydroelectric dam. Geophys. Res. Lett. 34 : L12809.

Maclntyre S., Jonsson A., Jansson M., Aberg J., Turney D.E. \& Miller S.D., 2010. Buoyancy flux, turbulence, and the gas transfer coefficient in a stratified lake. Geophys. Res. Lett. 37 : L24604, doi:10.1029/2010GL044164.

Maeck A., H. Hofmann, and A. Lorke, 2014. Pumping methane out of aquatic sediments - ebullition forcing mechanisms in an impounded river, Biogeosciences, 11, 2925-2938, doi:10.5194/bg-112925-2014.

Musenze R.S., Grinham A., Werner U., Gale D., Sturm K., Udy J. \& Yuan Z. 2014. Assessing the Spatial and Temporal Variability of Diffusive Methane and Nitrous Oxide Emissions from Subtropical Freshwater Reservoirs. Environmental Science \& Technology 48 : 14499-14507, doi: 10.1021/es505324h.

NTPC (Nam Theun 2 Power Company), 2005. Environmental Assessment and Management Plan - Nam Theun 2 Hydroelectric Project, Nam Theun 2 Power Company, Vientiane, Internal report, $212 \mathrm{p}$.

Sahlée E., Rutgersson A., Podgrajsek E. \& Bergström H., 2014. Influence from surrounding land on the turbulence measurements above a lake. Bound-Lay. Meteorol. 150 : 235-258

Serça D., Delmas R., Jambert C. \& Labroue L., 1994. Emissions of nitrogen oxides from equatorial rain forest in central Africa: origin and regulation of $\mathrm{NO}$ emission from soils. Tellus 46B : 243-254.

Serrano-Silva N., Sarria-Guzmàn Y., Dendooven L. \& Luna-Guido M., 2014. 
Methanogenesis and Methanotrophy in Soil: A Review. Pedosphere24 : 291-307.

St Louis V.L., Kelly C.A., Duchemin E., Rudd J.W.M. \& Rosenberg D.M., 2000. Reservoir surfaces as sources of greenhouse, gases to the atmosphere: A global estimate. Bioscience 50 : 766-775. doi:10.1641/0006-

3568(2000)050[0766:RSASOG]2.0.C.

Teodoru C.R., Nyoni F.C., Borges A.V., Darchambeau F., Nyambe I. \& Bouillon S., 2015. Dynamics of greenhouse gases $\left(\mathrm{CO}_{2}, \mathrm{CH}_{4}, \mathrm{~N}_{2} \mathrm{O}\right)$ along the Zambezi River and major tributaries, and their importance in the riverine carbon budget. Biogeosciences 12(8) : 24312453.

Tremblay A., Varfalvy L., Roehm C. \& Garneau M., (Eds.), 2005. Greenhouse Gas Emissions: Fluxes and Processes, Hydroelectric Reservoirs and Natural Environments. Environmental Science Series, Springer, Berlin, Heidelberg, New York, 732 p.

Wanninkhof R., 1982. Relationship between gas exchange and wind speed over the ocean. J. Geophys. Res. 97 : 7373-7382.

Xiao S., Wang Y., Liu D., Yang Z., Lei D. \& Zhang C., 2013. Diel and seasonal variation of methane and carbon dioxide fluxes at Site Guojiaba, the Three Gorges Reservoir. Journal of Environmental Sciences 25(10) : 2065-2071.

Yamamoto, S., Alcauskas J.B. \& Crozier T.E., 1976. Solubility of methane in distilled water and seawater. J. Chem. Eng., Data $21: 78-80$.

Yang L., Lu F., Wang X.K., Duan X.N., Song W.Z., Sun B.F., Chen S., Zhang Q.Q., Hou P.Q., Zheng F.X., Zhang Y., Zhou X.P., Zhou Y.J. \& Ouyang Z.Y., 2012. Surface methane emissions from different land use types during various water levels in three major drawdown areas of the Three Gorges Reservoir. J. Geophys. Res. Atmos. 117 : D10109.

Yang L., Lu F., Wang X., Duan X., Song W., Sun B., Zhang Q.\& Zhou Y., 2013. Spatial and seasonal variability of diffusive methane emissions from the Three Gorges Reservoir. J. Geophys. Res. Biogeo. 118(2) : 471-481.

Zhao Y., Wu B.F. \& Zeng Y., 2013. Spatial and temporal patterns of greenhouse gas emissions from Three Gorges Reservoir of China. Biogeosciences, 10(2) : 1219-1230. 